\title{
STATEMENTS OF FACT IN PLEADING UNDER THE CODES
}

In a recent case in New York ${ }^{1}$ the plaintiff alleged in his complaint that the promise for the breach of which he was suing was made in exchange for "a valuable consideration." The case went to the Court of Appeals upon the question whether this allegation is a "statement of fact" or a "conclusion of law". For many years prior to this decision the Appellate Division of the First Department had held this to be a "mere conclusion of law", 2 whereas the Appellate Division of the Third Department regarded it as a "statement of fact". 3 An examination of the authorities in other code jurisdictions reveals a conflict of authority. ${ }^{4}$ Under the common law system of pleading, however, there seems to have been substantial unanimity in holding , the statement to be a "conclusion of law". 5 In the case referred to. the Court of Appeals held the allegation "sufficient as a plain and concise statement' of the ultimate, principal and issuable fact of consideration".

The movement for "simplified procedure" began in this country about the middle of the last century. ${ }^{\circ}$ How comes it that after more than seventy years of discussion and judicial decision, a question of this kind can still be an open one? Why is it that eninent judges and lawyers took and still take opposite views upon this and similar questions? To answer these questions is the object of the present discussion. To do so we must begin with the provisions of the codes themselves. The New York Code, soon to be superseded by the newCivil Practice Act, provides as follows:

"The complaint must contain . . . . a plain and concise statement of the facts, constituting each cause of action, without unnecessary repetition." $\tau$

Substantially similar language is found in other codes. 8 In the new Civil

${ }^{1}$ California Packing Corp. v. Kelly Storage, etc. Co. (1920) 228 N. Y. 49, 126 N. E. 269.

'Fulton v. Varney' (1907) 117 App. Div. 572, 575, 102 N. Y. Supp. 608; Neatkirch v. IrcHugh (1914) 165 App. Div. 406. 409,150 N. Y. Supp. 1032.

"St. Lazurence Co. Nat. Bank of Canton v. Watkins (1912) 153 App. Div. 551, 553,138 N. Y. Supp. 116.

"Valuable consideration" is a "conclusion of law," Leach v. Rloodes (1874) 49

Ind. 291 ; it is an allegation of the issuable fact, Pomeroy, Code Remedies (4th ed.

1904) 562, and cases there cited.

Kean v. Mitchell (1865) 13 Mich. 207; Stone v. White (Mass. 1857) 8 Gray

589. It was, however, sufficient after verdict. Kean v. Mitchell, sitpra. ,

The movement goes back to 1848, in New York.

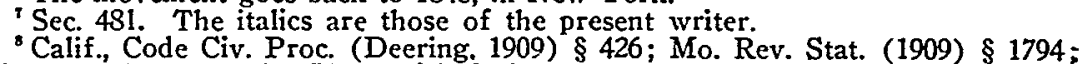

Federal Equity Rule 25. Cf. English Order 19, rule 2. 
Practice Act of New York, which was to take effect on the fifteenth of April of the present year, the matter is put as follows: 9

"Every pleading shall contain a plain and concise statement of the material facts, without unnecessary repetition. on which the party pleading relies, but not the evidence by which they are to be proved."

These provisions at first sight seem simple, and probably the men who first drew them so believed. That the simplicity is not real, however, becomes clear when one reads the hundreds, not to say thousands, of decisions which have passed upon the question whether in a given case the pleader has "stated the facts" in an acceptable manner. In many cases he is told that he has pleaded "evidentiary facts" instead of the "facts constituting the cause of action"; in many others he is held to have stated merely "conclusions of law".

All this is matter of common knowledge. Where lies the root of the difficulty? Primarily, it is believed, in the assumption that the problem is a simple one, that there is some clear, easily drawn and scientific distinction between so-called "statements of evidentiary facts", "statements of fact", and "conclusions of law", whereas in truth there is none. In other words, as is so often the case, a failure to analyze carefully the meaning of the terms used and so to form clear views as to the concept for which they stand is the chief cause of the doubt and confusion.

When such an analysis is made, it will appear at once that there is no logical distinction between statements which are grouped by the courts under the phrases "statements of fact" and "conclusions of law". It will also be found that many, although by no means all, pleadings held bad because they are said to plead "evidence" rather than "the facts constituting the cause of action" or defense really do nevertheless "state" the operative facts which the pleader will have to prove at the trial. but in a form different from that to which courts and lawyers are accustomed to recognize as a proper method of pleading. ${ }^{10}$

Typical of the commonly prevailing assumption of simplicity is the statement by an eminent writer on code pleading that under the code "facts" are not to be stated as under the common law system, i. e., according to their "legal effect", but as they "really are"-_dry, naked, actual facts". ${ }^{11}$ The slightest analysis will show that probably no more misleading, erroneous and practically harmful statement could possibly be made; that no pleading ever did or ever will be framed so as to carry out such a rule.

${ }^{\circ}$ Sec. 241. The slight change in wording makes no material alteration. It seems to be an attempt to state more explicitly the rules established by the decisions under the former wording.

${ }_{10}$ Compare Hohfeld, Fundamental Legal Conceptions (1919) 33.

12 "The issuable facts in a legal action, and the facts material to the relief in an equitable suit, should not only be stated to the complete exclusion of the law and the evidence, but they should be alleged as they actually existed or occurred, and not their legal effect, force, or operation. This conclusion follows as an evident corollary from the doctrine that the rules of law and the legal rights and duties 
The facts of life which compose the group of "operative facts" to which the law attaches legal consequences are always specific and not generic. That is to say, if B, for example, "strikes A with a club", the club used is always some specific club, different to some extent from any other club in existence. It will be of a certain length, thickness, weight, color, etc. Inasmuch as in an action for a simple battery it will be of no importance 12 whether the club was black or white, long or short, heavy or light, it is neither necessary nor desirable to specify, i. e., state specifically, what kind of club was used ; ${ }^{13}$ consequently we do not require the pleader to do more than describe the club generically-"a club". Similarly, in an action on the case for, let us say, negligently injuring the plaintiff by the operation of an automobile, the "operative" or "ultimate" facts proved at the trial will always be specific. It will appear that the defendant was driving a particular kind of automobile at some particular rate of speed, etc., etc. If now a plaintiff were to state the facts thus specifically in his complaint he would doubtless be told by the average court that he had "pleaded his evidence" and not the "facts constituting the cause of action". ${ }^{14}$ This would of course be .erroneous. ${ }^{15}$ What is according to accepted notions the proper way to

- of the parties are to be assumed, while the facts only which call these rules into operation, and are the occasion of the rights and duties, are to be spread upon the record. Every attempt to combine fact and law, to give the facts a legal coloring and aspect, to present them in their legal bearing upon the issues rather than in their actual naked simplicity, is so far forth an averment of law instead of fact; and is a direct riolation of the principle upon which the codes have constructed their sy'stem of pleading. The peculiar method which prevailed at the common Jaw has been fully described; it was undoubtedly followed more strictly and completely in certain forms of action than in others; in a few instances-as in a special action on the case-the declaration was framed in substantial conformity with the reformed theory. But in very many actions, and those in constant use, the -avermeuts were almost entirely of legal conclusions rather than of actual facts. The familiar allegations that the plaintiff had "bargained and sold" or "sold and .delivered", that the defendant "was indebted to the plaintiff," or "had and received -money to the plaintiff's use" and very frequently even the averment of a promise -made by the defendant, may be taken as familiar illustratious from among a -great number of other similar phrases which were found in the ordinary declara-tions. Rejecting as it does the technicalities, the fictious, the prescribed formulas, and the absurd repetitions and redundancies, of the ancient common-law system, the new pleading radically differs from the old in no feature more important and essential than this, that the allegations must be of dry, naked, actual facts, while the rules of law applicable thereto, and the legal rights and duties arising there-1 from, must be left entirely to the courts. While this doctrine has been uniformly recognized as correct when thus stated iu an abstract and general manner, it has sometimes been overlooked or disregarded in passing upon the sufficiency and -regularity of particular pleadings." (Italics by the present writer.) Pomeroy, Code Remedies (4th ed. 1904) 560, 561 .

${ }_{12}$ That is, so far as relates to showing that the plaintiff has a cause of action. The size, etc., of the club may become of importance, however, in many ways: in determining the amount of damages, etc.

${ }_{13}$ If the charge were assanlt "with a deadly weapou", the pleading at ouce becomes, as in some of the criminal cases, more specific as to the character of the inst rument used.

${ }^{14}$ Af Caughey v. Schuette (1896) 117 Cal. 223, 46 Pac. 666; see also L. \& N.R. R. v. Wolfe (1882) $80 \mathrm{Ky} .369$.

'See Illinois Steel Co. v. Ostrowski (1902) 194 IIl. 376, 384, 62 N. E. 822; .Omaha \& $R$. Ry. v. Wright (1896) 47 Neb. 886,66 N. W. 342. 
plead is merely a mode of stating the facts generically rather than specifically. ${ }^{15 a}$

It must of course he recognized that at times a pleader really does err by "pleading evidence", i. $\varepsilon$., by stating, generically or specifically, facts which do not form part of the group of operative facts, but are merely facts from which by some process of logical inference the existence of the operative facts can be inferred. More often, however, the "error" consists merely in pleading the operative facts more specifically than is usual.

So much for the cases involving the distinction between pleading "evidence" and "ultimate facts". Let us now examine "conclusions of law". The first thing noticed upon analysis is that a so-called "conclusion of law" is a generic statement which can be made only after some legal rule has been applied to some specific group of operative facts. Consider, for example, a statement in a pleading that "defendant owes plaintiff $\$ 500 "$. Standing by itself in a pleading this is usually treated as a mere "conclusion of law". It can, however, be made only when one knows certain facts and also the applicable legal rule. It is, in fact; the conclusion of a logical argument: Whenever certain facts, a, b, c, etc., exist, B (defendant) owes A (plaintiff) $\$ 500$; facts a, b, c, etc., exist; therefore $B$ owes $A \$ 500$. This being so, when the bare statement is made that " $B$ owes A $\$ 500$ " we may, if we wish, regard it as a statement in generic form that all the facts necessary to create the legal duty to pay money described by the word "owe" are true as between A and B. In dealing, for example, with misrepresentation, such statements are more often than otherwise regarded in exactly this way. The same statement may, however, under proper circumstances be merely a statement as to the law applicable to facts given or known, and so be purely a statement of a "conclusion of law". This is clearly brought out in the following illuminating statement by Jessel, M. R., in Eaglefield v. Marquis of Londonderry: 10

"A misrepresentation of law is this: when you state the facts, and state a conclusion of law, so as to distinguish between facts and law. The man who knows the facts is taken to know the law; but when you state that as a fact which no doubt involves, as most facts do, a conclusion of law, that is still a statement of fact and not a statement of law. Suppose a man is asked by a tradesman whether he can give credit to a lady, and the answer is 'You may, she is a single woman of large fortune'. It turns out that the man who gave that answer knew that the lady had gone through the ceremony of marriage with a man who was believed to be a married man, and that she had been advised that that marriage ceremony was null and void, though it had not been declared so by any Court, and it afterwards turned out they were all mistaken. that the first marriage of the man was void, so that the lady was married. He does

${ }^{15}$ However, the defendant could usually ask for a bill of particulars and thus obtain more specific information as to the nature of the plaintiff's case.

${ }_{10}$ (1876) L. R. 4 Ch. D. 693, 702. 
not tell the tradesman all these facts, but states that she is single. That is a statement of fact. If he had told him the whole story, and all the facts, and said, 'Now, you see, the lady is single', that would have been a misrepresentation of law. But the single fact he states, that the lady is unmarried, is a statement of fact, neither more nor less; and it is not the less a statement of fact, that in order to arrive at it you must know more or less of the law.

There is not a single fact connected with personal status that does not, more or less, involve a question of law. If you state that a man is the eldest son of a marriage, you state a question of law, because you must know that there has been a valid marriage, and that that man was the first-born son after the marriage or, in some countries, before. Therefore, to state it is not a representation of fact seems to arise from a confusion of ideas.

It is not the less a fact because that fact involves some knowledge or relation of law. There is hardly any fact which does not involve it. If you state that a man is in possession of an estate of $£ 10,000$ a year, the notion of possession is a legal notion, and involves knowledge of law; nor can any other fact in connection with property be stated which does not involve such knowledge of law. To state that a man is entitled to $£ 10,000$ Consols involves all sorts of law."

Coming now to the rules of pleading as they actually exist: it is as true in code pleading as it was in pleading at common law that a very large portion of the accepted inethods of statement are in this form, and are not statements of "dry, actua: fact", unmixed with "conclusions of law". To demonstrate the truth of this requires only the briefest examination of one or two typical cases.

In an early case in California the complaint alleged that "the said plaintiffs are the owners in fee as tenants in common, and have the lawful right and are entitled to the possession" of the described premises, and that "the said defendants wrongfully entered upon and are now in the wrongful and unlawful possession of said premises, and wrongfully and unlawfully withhold the possession thereof from said plaintiffs". "17

On demurrer this was held a sufficient statement of the "ultimate facts". - The statement that the plaintiffs "are owners in fee as tenants in common" obviously is of the kind under discussion and can be made only by one who knows the law as well as the non-legal facts involved. Since the facts are not otherwise given, however, it is properly treated as a generic statement of the facts, $i$. e., an assertion that some group, of facts, physical and mental, does exist which confers the "title" as described upon the plaintiff. The only real question is, whether it is desirable to have a more specific description of the facts upon which the plaintiff relies. So of all the other statements in the complaint under discussion: each and every one really involves "conclusions of law". Nevertheless, similar statements are generally regarded as sufficient. On the other hand, if the statement is put in a still more generic form, as. for example, that "the plaintiff is lawfully entitled to the possession"

${ }^{17}$ Payne v. Treadwell (1860) 16 Cal. 220. 
of certain land, it will probably be condemned as "a mere conclusion of law". Obviously, however, the only difference is that this latter statement is less specific than the other statements which are held sufficient. ${ }^{18}$

It must not be overlooked that occasionally a court shows that it senses, at least vaguely, the fact that the only real difference between the two classes of statements is the one here pointed out, $i$. $e$., as to the degree of generality or particularity with which the facts are stated. For example. in the case of Payne v. Treadiell, cited above, the court said: "A more particular statement of 'the circumstances' is not necessary under our system of practice." A clearer recognition of the true nature of the problem is found in the following passage from the opinion of Mitchell, J.. in Clark v. C. M. \& St. P. RY., ${ }^{19}$ in which it was held that it was sufficient in an action for injuries negligently inflicted to allege that the acts were done "negligently":

"It is urged that it is not sufficient to allege that an act was done negligently or carelessly : that this is merely a conclusion of law, and not a statement of an issuable fact: that the physical facts constituting the negligence must be alleged. It is. of course. an elementary rule of pleading that facts. and not mere conclusions of law, are to be pleaded. But this rule does not limit the pleader to the statement of pure matters of fact unmixed with any matter of law. TVhen a pleader alleges title to or ownership of property, or the execution of a deed in the usual form. these are not statements of pure facts. They are all conclusions from certain probative or evidential facts not stated. They are in part conclusions of law and in part statements of facts, or rather the ultiniate facts drawn from these probative or evidential facts not stated: yet, these forms are universally held to be good pleading. Some latitude therefore must be given to term 'facts' when used in a rule of pleading. It must of necessity include many allegations which are mixed conclusions of law and statements of facts, otherwise pleadings would become intolerably prolix, and mere statements of the evidence. Hence, it has become a rule of pleading that while it is not allowable to allege a mere conclusion of law containing no element of fact. yet it is proper. not only to plead the ultimate fact inferable from certain other facts, but also to plead anything which, according to the common and ordinary use of language. amounts to a mixed statement of facts. and of a legal conclusion. It may not be possible to formulate a definition that will always clescribe what is a mere conclusion of law. so as to distinguish it from a pleadable. inltimate fact, or that will define how great an infusion of conclusions of law will be allowed to enter into the comporition of a pleadable fact. Precedent and analogy are our only guides. And it is undoubtedly true that there will be found a want of entire judicial harmony in the adjudicated cases as to what are statements of fact and what are mere conclusions of law. And in holding one class of inferences as facts to be pleaded. and another as conclusions of law to be avoided. courts may have been often governed more by precedent than by a substantial difference in

${ }^{18}$ In Gladwin v. Stebbins (1852) 2 Cal. 103, such an allegation was held sufficient, but this view was abandoned in later cases. Payne v. Treadzuell (1860) 16 Cal. 220.

${ }_{19}$ (1881) 28 Minn. 69, 71. 
principle. But it has been quite generally held that the question of negligence in a particular case is one of mingled law and fact; that when we speak of an act as negligent or careless. according to the common use of languige. we state. not simply a conclusion of law, but likewise state an ultimate fact inferable from certain other facts not stated."

It will be readily seen that even this discussion, good as it is, is open to criticism, for it fails to recognize clearly that many of the statements rejected as "mere conclusions of law containing no element of fact" are in reality just as much "mixed statements of fact and a legal conclusion" as are the statements which are accepted as sufficient, and that the only basis for their rejection is that they are regarded as not sufficiently specific. It also confuses "statements of evidence" with what are really statements of the "ultimate facts" but in specific rather than in generic form.

Consider another example. It is commonly held that after alleging in proper form that a bond was executed and delivered to one $\mathrm{X}$, it is a "mere conclusion of law" to state that the plaintiff is "now the legal owner of the said bond". 20 Clearly this is an assertion in generic form that all the necessary facts exist to confer ownership of the bond upon the plaintiff, and the only real reason that can be given for rejecting it as insufficient is that it is too general. ${ }^{21}$

Under the system of pleading at common law the degree of particularity or generality which it was permissible to employ in alleging facts had been established by judicial decision or rule of court 22 so definitely that an intelligent attorney who knew what his case was really about could ordinarily go wrong only with difficulty. Indeed, in many cases such great generality was allowed that the pleadings failed to a large extent to do their work. How specific or how generic statements in a pleading may and must be can obviously not be settled by mere logic, but according to notions of fairness and convenience. The pleading should give the adversary and the court reasonable notice of the real nature of the claim or defense; nothing more should be required. Clearly it will be well, indeed necessary, to allow a pleader a certain amount of latitude in choosing a more or Iess generic or specific mode of stating his case. Some latitude was accordingly permitted at common law and more is allowed under the code. It is interesting in this connection to note that one of the chief criticisms of the common law system was the broadly generic character of the statements permitted in several of the common actions. - trover, detinue, ejectment, and general assumpsit, etc. When this is permitted the pleadings necessarily fail to do their work

"Smith v. Dean (1853) 19 Mo. 63.

a Note that one of the effects of permitting generic statements is that the specific facts which are proved at the trial are never really put in issue by the fleadings. Cf. Hohfeld, Fundamental Legal Conceptions (1919) 33.

2 The Hilary Rules of 1834 , for example, required pleas generally to be far less generic in form than had been previously allowed. 
properly in giving fair notice of the claim or defense to the court and the opposite party. ${ }^{23}$

Upon the adoption of the reformed procedure, which swept away the common law forms and precedents and substituted only the abstract statement that the "facts" were to be stated in "plain and concise language", it was inevitable, as the foregoing analysis shows, that a period of chaos and confusion should follow. As we have seen, the error lay in assuming, as did Pomeroy, that a pleading could recite physical and mental facts "as they actually happened" without any intermixture of "legal conclusions". Because of the ambiguity of this general requirement of the code it became necessary once more to build up by judicial decision standards of particularity and generality. "Precedent and analogy" were the only guides; without those, the pleader and the courts were left to blaze new paths through a trackless wilderness. ${ }^{24}$

Had the framers of the earliest codes of simplified procedure realized the true nature of the pleader's problem, nearly all the chaos and confusion could have been obviated by the adoption, preferably by rule of court, of a series of forms which would be regarded as sufficient, covering all the more common actions. ${ }^{25}$ This was done in an occasional jurisdiction with the result that pleaders found the use of the reformed system relatively simple and easy. ${ }^{26}$ If, as seems probable, the fundamental outlines of code pleading are to be retained, it is highly desirable that in each jurisdiction a set of forms be adopted. Obviously this task should be delegated to the highest court in the state, so that, as experience shows the need for the alteration of old forms or the adoption of new, changes may be made easily and quickly, and without recourse to the legislature. When and, it is believed, only when a set of officially recognized forms is at the disposal of pleaders can we expect.to do away with useless litigation of the kind exemplified in the case which forms the text of the present discussion.

Colvmbia Law School

WALTER WHFELER COOK

"See supra, footnote 22 . code requirement that the "facts constituting the cause of action" be stated and substituting a more vague requirement, as suggested, for example, by Professor Clarke B. Whittier in his discussion of Notice Pleading in (1918) 31 Harvard Law Rev. 501. The American Judicature Society after careful study has apparently decided that it is not wise to attempt to change substantially the present code requirement in this respect. See their Bulletin XIII. With this view the present writer fully agrees.

${ }^{23}$ But not required. It is often overlooked that the use of the common-law forms was to some extent not absolutely required by the rules of common law pleading.

${ }^{20}$ The first Connecticut simplified Practice Act (1879) was supplemented by orders, rules and forms prescribed by the judges of the Superior Court. The Act itself and the supplementary orders, rules and forms were prepared by a commission. The commission, in a Prefatory Note to its report, stated that the forms were "designed to guide, not to hamper, the profession", and that other forms were permissible. For fnrther information, see the Prefatory Note to the official Connecticut Practice Book of 1908. 